\title{
Review of past and recent fluvial dynamics in the Beni lowlands, NE Bolivia
}

\author{
Anna Plotzki, Bern, Jan-Hendrik May, Beijing, \\ Heinz Veit, Bern
}

\section{Introduction}

The Beni basin in north-eastern Bolivia is part of the south-western Amazon Basin. Its central part consists of the Llanos de Moxos, one of the largest seasonally inundated savannahs in the world $\left(150,000 \mathrm{~km}^{2}\right)$ (BoixAdera et al. 2003) (Fig. 1). Fluvial and hydrological regimes are highly variable in space and time, which is evident in the diverse inundation patterns, large-scale river migrations (Allenby 1988; DumONT 1996; HANAGARTH 1993; PLAFKER 1964) and various traces of former river courses found in the basin. Despite this rich fluvial record, very little is known with regard to the longerterm and modern variations of the fluvial system in the Beni lowlands. So far, most palaeohydrological studies in tropical South America have focused on the late Quaternary fluvial sedimentary and geomorphologic records along the central Amazon River and its main tributaries; as is summarized in LATRUBESSE (2003).

For the Beni basin, more about the longer-term evolution of the Río Mamoré and Río Beni may be found in Allenby (1988), Hanagarth (1993) and Dumont (1996), who described different generations of palaeorivers and discussed potential tectonic control on the associated river shifts. Most published studies, however, have been concerned with hydrogeomorphic variability on short time scales and mainly examine the mechanisms and frequencies of flooding (AALTO et al. 2003; Bourrel \& Pouilly 2004; Bourrel et al. 2009; HAmilton et al. 2004; HamiLton 2009; RonCHAIL et al. 2005), sediment composition, discharge and fluvial geomorphology of the Río Mamoré and the Río Beni (Charrière et al. 2004; Dumont \& Fournier 1994; Elbaz-Poulichet et al. 1999; Gautier et al. 2007; GuYOT et al. 1999; GuYot et al. 2007), as well as their water chemistry (GUYOT et al.1991; Roche \& JAUREGUI 1988). While all of these short-term studies have contributed to recognition of a highly variable hydrological system in the Beni basin, virtually no data are available with regard to type, magnitude and controlling factors of fluvial changes in the past.

This article focuses on (i) a review of existing literature concerned with past and recent fluvial processes in the Beni basin; (ii) reports on the use of remote sensing data to highlight aspects of longer-term fluvial variability in the Beni lowlands; and (iii) discusses findings with regard to potential controlling factors.

\section{Study area}

The Beni basin is drained by four main rivers: the Río Beni, the Río Mamoré, the Río Grande and the Río Iténez (Fig. 1). Together they form the Río Madeira, which is a main tributary of the Amazon River. The basin is situated between the Andes to the west and the Brazilian Precambrian Shield to the east. Elevations range between $130 \mathrm{~m}$ a.s.l. in the north and $\sim 200 \mathrm{~m}$ a.s.l. in the south (HANAGARTH \& SARMiento 1990). With less than $10 \mathrm{~cm} / \mathrm{km}$, the gradient is very low (Dumont \& Fournier 1994). The foreland basin is filled with Tertiary and Quaternary alluvial deposits of Andean origin (SuÁrEZ-SorUco 2000), which thicken gradually from $800 \mathrm{~m}$ in the east (PLAFKer 1964) to $5,000 \mathrm{~m}$ along the Andean border in the west (DumonT \& Fournier 1994). In the central Beni basin an anticlinal uplifted zone, the Bala-Rogagua line (Fig. 1), proceeds in a SW-NE direction (Allenby 1988; Dumont 1996; Hanagarth 1993). According to Allenby (1988) the uplift is the result of upwarping of the Brazilian Shield underlying the Beni basin. The SW-NE orientation of the line coincides with fracture patterns in the crystalline Brazilian Shield. The uplift is probably very small, in the range of some tens of metres over hundreds of metres (AlLENBY 1988). Very little information is available about the mechanisms of the BalaRogagua line and its formation.

Total annual rainfall in the Beni basin increases from $1,200 \mathrm{~mm}$ in the south to $2,000 \mathrm{~mm}$ in the north, due to the decreasing influence of the dry air masses coming from the south. The Andes divert the humid air coming from the NE to the $\mathrm{SE}$, thus causing heavy rainfall in the Andean foothills where, for example, the Chapare region (Fig. 1) receives more than 6,000 mm/yr (GUYOT \& Wasson 1994; Roche \& JAuregui 1988; Ronchail et al. 2005). The area is affected by a marked seasonality characterized by wet summers with extensive inundations and dry winters. Southward migration of the Intertropical Convergence Zone (ITCZ) and onset of the South American Summer Monsoon (SAMS) lead to heavy convective rainfall over the Beni basin in austral summer (GARREAUD et al. 2009; VERA et al. 2006; ZHOU \& LAU 1998).

The central part of the Beni basin (Llanos de Moxos) is characterized by extensive treeless savannahs. Trees are restricted to elevated areas such as river levees and forest islands which are not affected by the seasonal inundations (LANGSTroth 1996; MAYLE et al. 2007; PlAFKER 1964). The soils are predominantly imperfectly to very poorly drained clayey soils, with clay 


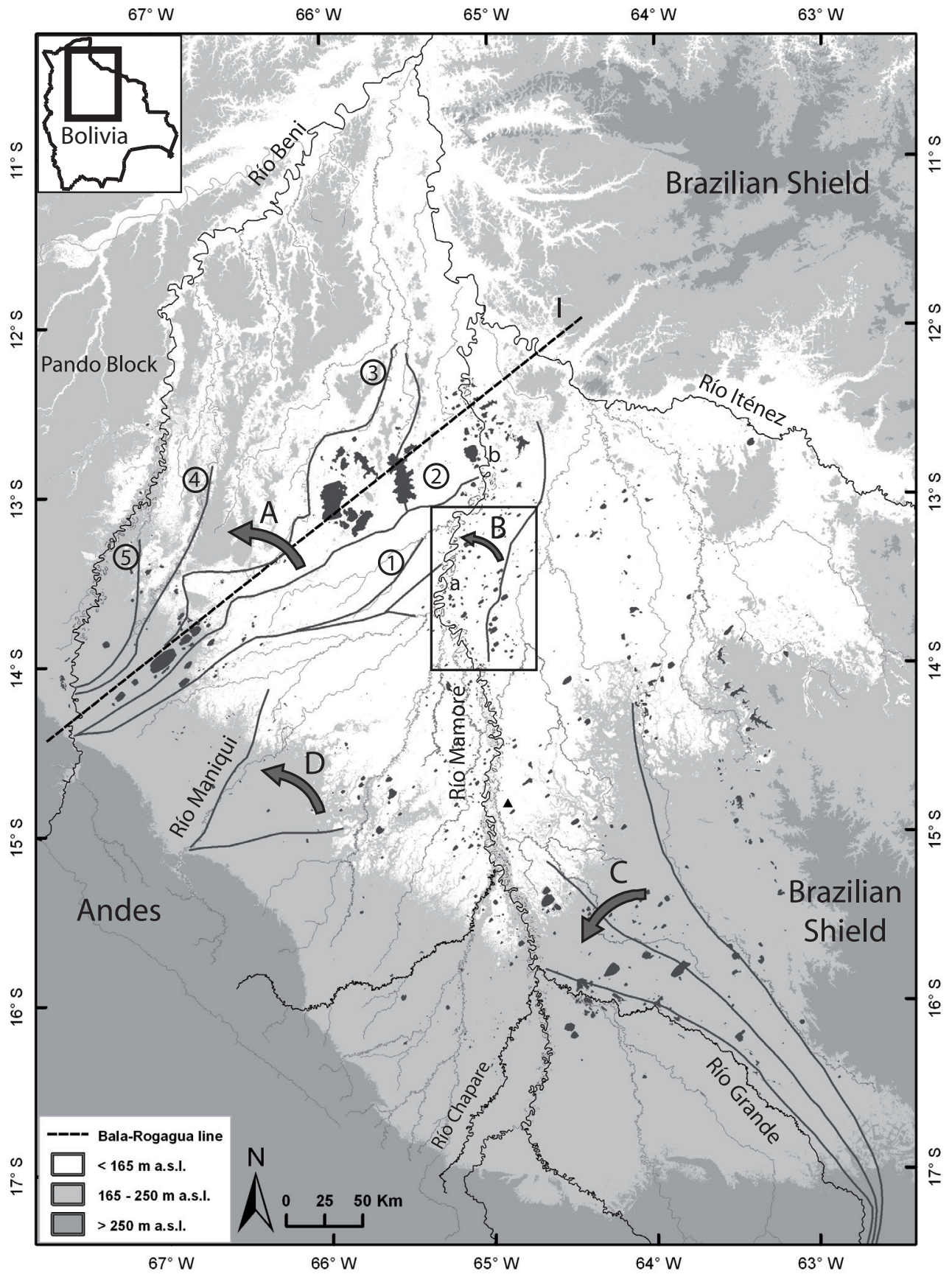

Fig. 1: Overview of Beni basin. (I) Bala-Rogagua line (Hanagarth 1993). River migrations: A) Río Beni (phases 1-5) (Hanagarth 1993), B) Río Mamoré, C) Río Grande (Dumont 1996; Hanagarth 1993), D) Río Maniqui (Hanagarth 1993). Inset, see Fig. 2. The city of Trinidad is marked by a triangle. White area ( $<165 \mathrm{~m}$ a.s.l.) primarily represents the Llanos de Moxos plains (elevations based on SRTM data).

Überblick über das Beni-Becken

Vue d'ensemble du bassin de Beni

Cartography: U. Lombardo, A. PlotzKi 
content up to $90 \%$, even though saline soils (salitrales) have also been described in the Llanos de Moxos (BoiXAdera et al. 2003; HANAgArTH 1993).

\section{Methodology}

Satellite images (Landsat TM 2001, Google Earth 2002) were used for mapping fluvial morphologies, enabling observations over a large area and a wide range of spatial scales. More specifically, oxbow lakes were mapped in detail at selected study sites along the modern Río Mamoré and a former belt of the Río Mamoré. Parameters such as amplitude, width of meanders and width of the channels were measured. Visual interpretation was based on the identification of different shapes, sizes, colours, textures and patterns of the objects in the images. All image processing and analysis was done with ArcGis 9.3.

\section{Recent hydrological dynamics in the Beni basin}

The main rivers, the Río Mamoré, Río Grande and Río Beni, originate in the Andes and carry huge amounts of sediment (64 m t/yr Río Mamoré and 165 m t/yr Río Beni at their confluence) (GuYot et al. 1999). According to Guyot et al. (1996) up to $60 \%$ of the sediment transported by the Río Mamoré is trapped in the basin. The rivers draining the Andes are known as white water rivers (Pouilly \& BECK 2004; SiOLI 1984). In contrast, clear water rivers drain the crystalline Brazilian Shield (e.g. Río Iténez) or the floodplains (e.g. Río Ibare, Río Mocoví) and transport only minor suspended sediment loads (IBAÑez \& PouIlly 2004; Sioli 1984). The mean annual discharge of the Río Mamoré at Trinidad is $3,150 \mathrm{~m}^{3} / \mathrm{s}$, increasing to $8,340 \mathrm{~m}^{3} / \mathrm{s}$ after confluence with Río Iténez (Bourrel et al. 2009). Together, the Río Mamoré and the Río Beni have a discharge of $17,000 \mathrm{~m}^{3} / \mathrm{s}$ when they join to form the Río Madeira (Roche \& JAuregui 1988). River discharge, however, depends greatly on inter-seasonal variations in rainfall. In the rainy season, discharge at Trinidad (Puerto Varador) may reach $7,600 \mathrm{~m}^{3} / \mathrm{s}$ (maximum daily flow 1988-1999) (RoNCHAIL et al. 2005), whereas in the dry season it may be less than $1,000 \mathrm{~m}^{3} / \mathrm{s}$ (GUYOT 1993).

As mentioned above, the Llanos de Moxos are subject to severe seasonal inundations during the austral summer, with inundated areas ranging from 2,000$78,000 \mathrm{~km}^{2}$ and occasionally reaching $150,000 \mathrm{~km}^{2}$ (Hamilton et al. 2004; Hanagarth \& Sarmiento 1990; HANAGARTH 1993).

Bourrel and Pouilly (2004) and Bourrel et al. (2009) describe an exogenic and an endogenic inundation process: flooding in the Llanos de Moxos can either be caused by rainfall in the Andes and subsequently rising waters in rivers with Andean headwaters, e.g. the Río Mamoré (exogenic), or it can be the result of local precipitation over the plain, leading to ponding, rising groundwater tables and overflow of local rivers (endogenic). The magnitude of the individual flood events is variable and depends on the interaction of exogenic and endogenic processes. The most severe inundations, for example in 1992 and 1993 (Bourrel \& Pouilly 2004; BoUrRel et al. 2009), were caused by a combination of both processes, when endogenic flood waters were blocked by high water levels along the Andean rivers, so that those could not serve as drainage routes. Other large inundation events since 1950 have been reported for 1956, 1980 (CHARRIÈre et al. 2004), 2007, 2008 and 2010 (own observations).

Inundation of the Moxos plain is favoured by the low gradient, the almost impermeable clayey soils, and the outcropping Brazilian Shield in the west and northwest (Fig. 1), representing a topographic barrier and thus retaining the water in the basin (HANAGARTH 1993). Inundation water levels can reach up to $2 \mathrm{~m}$ in the plain (Bourrel \& PouIlly 2004) but in most areas do not exceed $1 \mathrm{~m}$ (HANAgARTH 1993). The area west of the Río Mamoré is subject to more extensive inundations, as this is the topographically most depressed area in the Llanos de Moxos and is characterized by an extensive fluvial network (Bourrel \& Pouilly 2004; Bourrel et al. 2009; Dumont 1996).

\section{Past fluvial processes in the Beni basin - large-scale river avulsions}

\subsection{Avulsions in the Beni plain}

Large-scale river migrations in the Beni basin have been reported for the Río Beni, Río Grande and Río Maniqui (Allenby 1988; Dumont 1996; Hanagarth \& Sarmiento 1990; Hanagarth 1993; Plafker 1964) (Fig. 1). Strikingly, all of them show an anti-clockwise migration, thus changing flow direction from $\mathrm{NE}$ to $\mathrm{N}$ or $\mathrm{N}$ to $\mathrm{NW}$, respectively. Anti-clockwise shifts were also noted for some smaller rivers, such as the Río Secure and Río Madidi (Hanagarth 1993). All of these river shifts have been explained by tectonic uplift and related tilting. More specifically, AlLEnBy (1988) proposed uplift along the Bala-Rogagua line that forced the Río Beni to change its course away from the elevated area (Fig. 1, Migration A). The traces of former courses are still visible in the plain between the Río Beni and Río Mamoré and are partly used today by small underfit rivers. HANAGARTH (1993) and Dumont (1996) differentiated five palaeo-phases for the Río Beni, reflecting its stepwise migration from NE to N. According to Dumont (1996), the third phase 
may have been active around 2,500 years ago, but no further information is available with regard to location, dated material or applied methods. It is remarkable, however, that the first two phases of the Río Beni seem to have migrated towards the Bala-Rogagua line.

Migration of the Río Grande in the SE part of the basin from a northerly course to a NW direction is indicated by a broad belt of gallery forest (Fig. 1, Migration C). Furthermore, lakes on the craton border may have been ponded by alluvial aggradation in relation to a former Río Grande, as the modern fluvial network in the area is poorly developed and characterized by minor, clear water rivers unable to provide sufficient sediment for regional aggradation (DumonT 1993; Dumont \& Fournier 1994). The shift of the Río Grande may have been caused by uplift of the Andean forebulge region along the margin of the outcropping Brazilian Shield in the south-eastern part of the basin (Allenby 1988; Dumont \& Fournier 1994; Dumont 1996; Hanagarth 1993; Horton \& DeCelles 1997; Horton \& DeCelles 2001).

The Río Maniqui in the central Beni basin has also been shifting mainly anti-clockwise (Fig. 1, migration D), and is still migrating: one displacement was recorded for the early 1960s and the latest one started in 1992 (HANAGARTH 1993) and was probably established before 2001. The early Río Maniqui stages, however, seem to have migrated clockwise, although an exact reconstruction of the phases is hampered by the complexity of the old fluvial traces (HANAGARTH 1993).

Using satellite imagery analysis, a previously unreported paleocourse of the Río Mamoré in the northern part of the Beni basin was revealed (Fig. 1, Migration B and Fig. 2). Evidently, the Río Mamoré changed its course in an anticlockwise direction from NE to NNE.

In summary, all of the larger rivers with headwaters in the Andes show convincing evidence of large-scale river shifts. Apart from the last two phases of Río Maniqui, and the unconfirmed date of phase three of the Río Beni (Dumont 1996), however, none of these river shifts can be put into a temporal frame yet.

\subsection{Timing and causes of large-scale river shifts - case study Río Mamoré}

In the absence of chronological data for these largescale river shifts, the observed similarity between the rivers with regard to their anti-clockwise shifting direction generally supports the idea of tectonics as trigger. However, it is crucial to note that the Río Mamoré, as well as the first stages of the Río Beni, apparently shifted towards the uplifted Bala-Rogagua line (see Fig. 1: Bala-Rogagua line (I), migration A, phases 1 and 2, and migration B), even though, in gen- eral, rivers deflect away from zones of uplift (BRIDGE 2003; Schumm 2005). Therefore it seems unlikely that uplift along this line controlled the shifts of the Río Mamoré or the early Río Beni.

In the north of the Beni basin the sinuosity of the Río Mamoré decreases and the meanders show a more open pattern (Fig. 1, Point a and Fig. 2) (Allenby 1988). Further to the north, the sinuosity decreases even more when the river actually crosses the BalaRogagua line (Fig.1, Point b). Rapids and bedrock outcrops are encountered here, indicating the presence of the underlying crystalline Brazilian craton near the surface (Allenby 1988; Dumont \& Fournier 1994; Dumont 1996).

The reduced sinuosity of the Río Mamoré could be explained by the tectonic uplift of the Bala-Rogagua line, as rivers can adjust to changes in slope, for example induced by tectonic uplift across the course of a river, by decreasing sinuosity as slope decreases (Bridge 2003; Holbrook \& Schumm 1999; Ouchi 1985; Schumm 2005). Several examples of such adjustments to tectonic uplift are summarized in Schumm (2005). Allenby (1988) suggests that the observed decrease in sinuosity is relatively young, as abandoned oxbows close to the present course show a higher sinuosity than recent ones. Following this suggestion, which points to a relatively young uplift and sinuosity decrease, the following sequence of events is tentatively proposed: (i) the Río Mamoré changed its course (possibly in accordance with the first Río Beni shifts) and was highly sinuous; (ii) then uplift along the Bala-Rogagua line occurred, causing the sinuosity decrease upstream of and over the uplifted area. In this scenario, uplift along the Bala-Rogagua line would not be responsible for the shifts of the Río Mamoré and/or the early stages of the Río Beni.

In contrast, tectonic activity in the SE part of the basin related to uplift along the margin of the Brazilian Shield and the Andean forebulge (LYON-CAEN et al. 1985) could have had an influence on the Río Mamoré and Río Beni shifts by tilting the entire plain in a NW direction. This would explain their shifts in western direction. Lateral tilting may cause down-tilt avulsions of rivers if tilt rates are high (HolвRooк \& Schumm 1999). This could potentially mean that the Río Grande, the Río Mamoré and the early stages of the Río Beni shifted roughly contemporaneously, caused by the same uplift pulse in the SE. On the other hand, uplift may have continued slowly over longer time periods. In this case it is tectonics and uplift that create the boundary conditions for avulsions (e.g. changes in slope) and they might not have directly triggered these large-scale river shifts. In fact, avulsions may occur due to hydrological/climatic changes in the drainage basin 

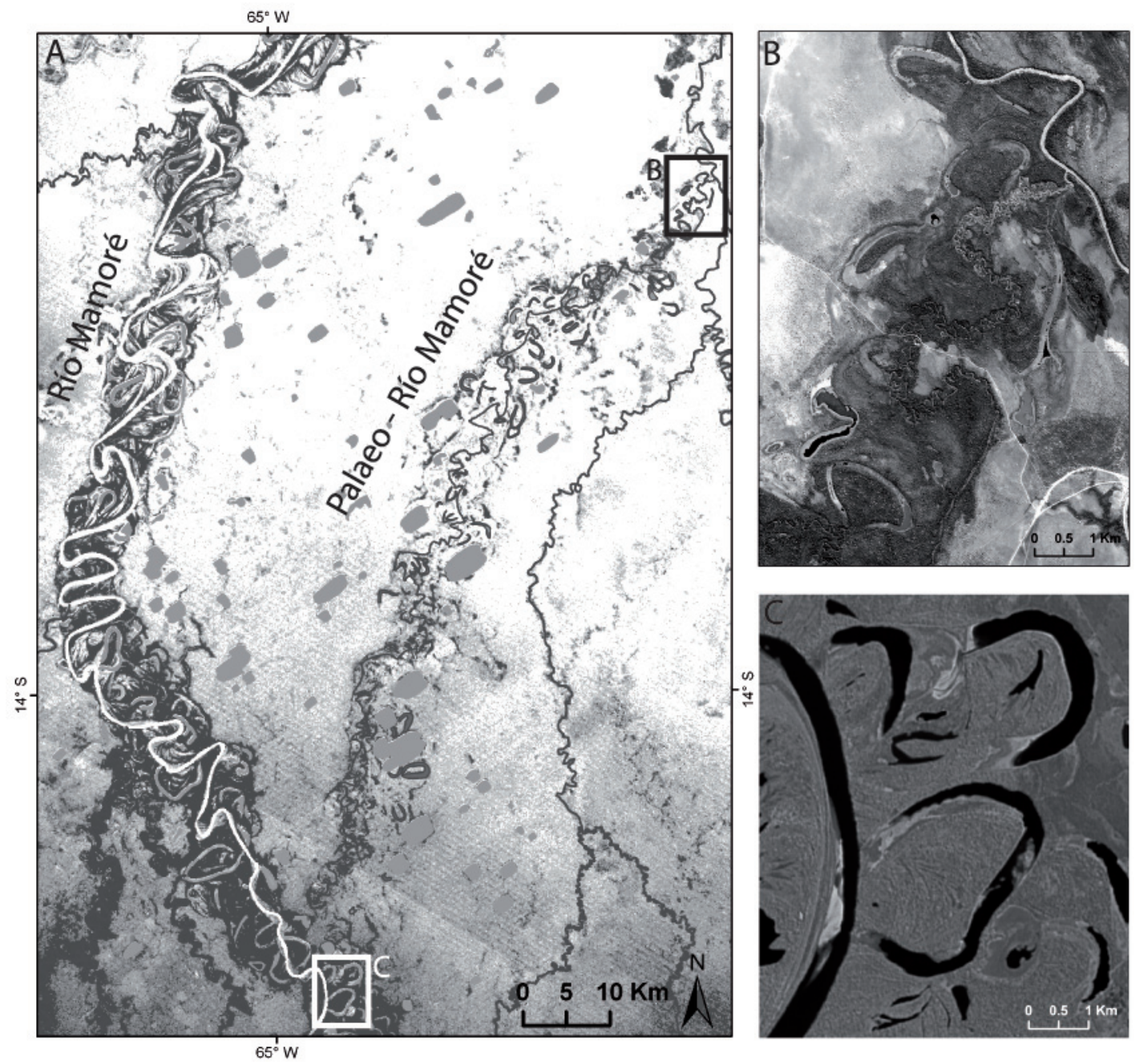

Fig. 2:A) Former and present courses of the Río Mamoré (based on SRTM data). Insets, see B and C. B) Oxbows of the Palaeo-Mamoré (Google Earth 2002), C) Oxbows of the Río Mamoré today (Landsat 2001). Note the difference in amplitude, width of the meanders and width of the former channel.

A) Früherer und aktueller Verlauf des Río Mamoré (basierend auf SRTM-Daten). Kästchen siehe B und C. B) Mäander des Paläo-Mamoré (Google Earth 2002), C) Mäander des aktuellen Río Mamoré (Landsat 2001)

A) Lits anciens et actuels du Río Mamoré (traçés basés sur les données SRTM). Encarts, voir B et C. B) Bras morts du Paléo-Mamoré (Google Earth 2002), C) Bras morts du Río Mamoré actuel (Landsat 2001)

Cartography: U. Lombardo, A. Plotzki

and accompanying changes in discharge and sediment supply, and thus, are not necessarily related to tectonic activity. More specifically, increased discharge and sediment supply may lead to a reduction in the capacity of the channel to accommodate the increased amount of sediment, thus building up an avulsion threshold. If the river is near the avulsion threshold, a short-term event (trigger), e.g. a seismic event or a flood, can cause the avulsion (BRIDGe 2003; Jones \& SCHumm 1999; MAKASKe 2001; Mohrig et al. 2000; Schumm 2005).

The paleocourse of the Río Mamoré is well preserved and characterized by relicts of meanders, oxbow lakes and a broad fluvial belt represented by remnants of gallery forest. The fluvial belt is up to $8 \mathrm{~km}$ wide and has thus, almost the same width as the modern mean- 
der belt (up to $10 \mathrm{~km}$ ). A total of 86 oxbows have been mapped along a $100 \mathrm{~km}$ long section. More oxbows are visible in the satellite imagery but not clearly identifiable. Measuring and comparing parameters such as amplitude, width of the meanders and width of the former channel to the active river illustrates the overall smaller dimensions of the palaeocourse (Fig. 2, B and C). The width of the former channel to the active one is a ratio of 0.45 . These parameters point to a reduced discharge of the Palaeo-Mamoré compared to the recent one. Therefore, a change in the hydrological regime of the Río Mamoré becomes evident, implying an increase in discharge over time. As for the Río Mamoré, Dumont (1996) has already stated that the first two Río Beni phases show much smaller traces than the subsequent ones, and has related them to a mid-Holocene dry period in the southern Beni basin during the period 7,000-5,000 14C yrs BP (SERVANT et al. 1981). In the SW Amazon Basin and the adjacent Andean uplands, this dry period was later widely corroborated by pollen and sedimentary evidence from lakes and attributed to a minimum in summer insolation at $10-15^{\circ} \mathrm{S}$ during the early to mid-Holocene (Аввотт et al. 1997; Аввотт et al. 2003; Behling \& Hooghiemstra 2001; Behling et al. 2001; Burbridge et al. 2004; Bush et al. 2004; MAYLE et al. 2000; MAYLE 2011; TAYLOR et al. 2010). In turn, an increase in insolation from the mid-Holocene on would have led to renewed and increased humidity, warmer summer temperatures and a strengthened South American Summer Monsoon (TAYLOR et al. 2010). Thus, the transition to more humid conditions in the late Holocene may have caused increased discharge and/or sediment supply in the rivers, such as the Río Mamoré and the Río Beni, resulting in a reduction of the channel's capacity to accommodate the increased amount of water and sediments, and ultimately causing avulsions. In this scenario, the Río Mamoré avulsion as well as the avulsions associated with the two early Río Beni stages would have occurred in the mid- to late Holocene, which is in agreement with the unverified age of the third Río Beni migration (2,500 years ago) (Dumont 1996), presenting a testable hypothesis for future research.

\section{Conclusions}

Large-scale river migrations have been reported in the Beni basin for the Río Beni, Río Grande and Río Maniqui. Strikingly all of them show an anti-clockwise migration, and thus changing flow direction from NE to $\mathrm{N}$ or $\mathrm{N}$ to $\mathrm{NW}$, respectively. Based on analysis of satellite images, a previously unreported paleocourse of the Río Mamoré in the northern part of the Beni basin was revealed (Figs. 1 and 2), which also changed its course in an anti-clockwise direction and probably experienced an increase in discharge between the two phases. Tectonic uplift along the Bala-Rogagua line has been held responsible for the Río Beni shifts. However, both the Río Mamoré, as well as the first stages of the Río Beni, apparently shifted towards the BalaRogagua line. It therefore seems unlikely that uplift along this line controlled the shifts of the Río Mamoré or the early Río Beni. Here, late Quaternary and/or Holocene climatic alterations may offer an alternative explanation for the observed changes in the fluvial system. This can be corroborated by discharge changes over time as deduced from changes in meander geometries, with a clear increase of channel dimensions (Río Mamoré). Thus, it is hypothesised that the transition to more humid conditions in the late Holocene is the probable cause of avulsion of the Río Mamoré and the first phases of Río Beni.

\section{Acknowledgements}

This research was funded by the Swiss National Science Foundation (SNF 200021-1222).

\section{References}

Aalto, R., Maurice-Bourgoin, L., Dunne, T., MontGOMery, D.R., NitTrouer, C.A. \& J.L. Guyot (2003): Episodic sediment accumulation on Amazonian flood plains influenced by El Niño/Southern Oscillation. In: Nature 425: 493-497.

Аввотt, M.B., Seltzer, G.O., Kelts, K.R. \& J. SouTHON (1997): Holocene paleohydrology of the tropical Andes from lake records. - In: Quaternary Research 47, 1: 70-80.

Аввott, M.B., Wolfe, B.B., Wolfe, A.P., Seltzer, G.O., Aravena, R., Mark, B.G., Polissar, P.J., Rodbell, D.T., Rowe, H.D. \& M. VuILLE (2003): Holocene paleohydrology and glacial history of the central Andes using multiproxy lake sediment studies. - In: Palaeogeography, Palaeoclimatology, Palaeoecology 194,1-3:123-138. Allenby, R.J. (1988): Origin of rectangular and aligned lakes in the Beni Basin of Bolivia. - In: Tectonophysics 145, 1-2:1-20.

Behling, H. \& H. Hooghiemstra (2001): Neotropical savanna environments in space and time: Late Quaternary interhemispheric comparisons. - In: MARKGRAF, V. (ed.): Interhemispheric climate linkages. - Maryland Heights: Academic Press: 307-323.

Behling, H., Keim, G., Irion, G., Junk, W. \& J. Nunes DE Mello (2001): Holocene environmental changes in the Central Amazon Basin inferred from Lago Calado (Brazil). - In: Palaeogeography, Palaeoclimatology, Palaeoecology 173, 1-2: 87-101.

Boixadera, J., Poch, R.M., Garcia-Gonzalez, M.T. \& C. VizcaYno (2003): Hydromorphic and clay-related processes in soils from the Llanos de Moxos (northern Bolivia). - In: Catena 54, 3: 403-424. 
Bourrel, L. \& M. Pouilly (2004): Hidrología y dinámica fluvial del Río Mamoré. - In: Pouilly, M., Beck, S.G., Moraes R., M. \& C. Ibañez (eds): Diversidad biológica en la llanura de inundación del Río Mamoré. Importancia ecológica de la dinámica fluvial. - La Paz: Fundacíon Simón I. Patiño: 95-116.

Bourrel, L., Phillips, L. \& S. Moreau (2009): The dynamics of floods in the Bolivian Amazon Basin. - In: Hydrological Processes 23, 22: 3161-3167.

BRIDGE, J.S. (2003): Rivers and floodplains. Forms, processes, and sedimentary record. - Oxford: Blackwell Publishing.

Burbridge, R.E., Mayle, F.E. \& T.J. Killeen (2004): Fifty-thousand-year vegetation and climate history of Noel Kempff Mercado National Park, Bolivian Amazon. - In: Quaternary Research 61, 2: 215-230.

Bush, M.B., Silman, M.R. \& D.H. Urrego (2004): 48,000 years of climate and forest change in a biodiversity hot spot. - In: Science 303, 5659: 827-829.

Charrière, M., Bourrel, L., Gautier, E. \& M. Pouilly (2004): División geomorfológica del Río Mamoré. In: Pouilly, M., Beck, S.G., Moraes R., M. \& C. Ibañez (eds): Diversidad biológica en la llanura de inundación del Río Mamoré. Importancia ecológica de la dinámica fluvial. - La Paz: Fundacíon Simón I. Patiño: 77-94.

Dumont, J.F. (1993): Type of lakes as related to neotectonics in western Amazonia. - Proceedings of the International Symposium on the Quaternary of Amazonia, Universidad do Amazonas, 8.-13.11.1992, Manaus, Brasil: 99-102.

Dumont, J.F. (1996): Neotectonics of the SubandesBrazilian craton boundary using geomorphological data: the Marañon and Beni basins. - In: Tectonophysics 259, 1-3: 137-151.

Dumont, J.F. \& M. Fournier (1994): Geodynamic environment of Quaternary morphostructures of the subandean foreland basins of Peru and Bolivia: characteristics and study methods. - In: Quaternary International 21: 129-142.

Elbaz-Poulichet, F., Seyler, P., Maurice-Bourgoin, L., Guyot, J.L. \& C. Dupuy (1999): Trace element geochemistry in the upper Amazon drainage basin (Bolivia). - In: Chemical Geology 157, 3-4: 319-334.

Garreaud, R.D., Vuille, M., Compagnucci, R. \& J. Marengo (2009): Present-day South American climate. - In: Palaeogeography, Palaeoclimatology, Palaeoecology 281, 3-4: 180-195.

Gautier, E., Brunstein, D., Vauchel, P., Roulet, M., Fuertes, O., Guyot, J.L., Darozzes, J. \& L. Bourrel (2007): Temporal relations between meander deformation, water discharge and sediment fluxes in the floodplain of the Rio Beni (Bolivian Amazonia). - In: Earth Surface Processes and Landforms 32, 2: 230248.

Guyot, J.L., Corbin, D., Quintanilla, J. \& H. Calle (1991): Hydrochimie de lacs dans la région de Trinidad (Amazonie bolivienne). Influence d'un fleuve andin: le
Rio Mamoré. - In: Revue d'Hydrobiologie Tropicale 24, 1:3-12.

Guyot, J.L. (1993): Hydrogéochemie des fleuves de l'Amazonie Bolivienne. - Ph.D Thesis, Université de Bordeaux, Institut de Géologie-Géochimie.

GuYot, J.L. \& J.G. WASSON (1994): Regional pattern of riverine dissolved organic carbon in the Amazon drainage basin of Bolivia. - In: Limnology and Oceanography 39, 2: 452-458.

Guyot, J.L., Filizola, N., Quintanilla, J. \& J. Cortez (1996): Dissolved solids and suspended sediment yields in the Rio Madeira basin, from the Bolivian Andes to the Amazon. Erosion and sediment yield: global and regional perspectives. - Proceedings of the Exeter Symposium «Erosion and Sediment Yield: global and regional perspectives», 15.-19.7.1996, Exeter, IAHS Publications, Exeter: 55-63.

Guyot, J.L., Jouanneau, J.M. \& J.G. Wasson (1999): Characterisation of river bed and suspended sediments in the Rio Madeira drainage basin (Bolivian Amazonia). - In: Journal of South American Earth Sciences 12, 4: 401-410.

Guyot, J.L., Jouanneau, J.M., Soares, L., Boaventura, G.R., Maillet, N. \& C. Lagane (2007): Clay mineral composition of river sediments in the Amazon Basin. - In: Catena 71, 2: 340-356.

Hamilton, S.K., Sippel, S.J. \& J.M. Melack (2004): Seasonal inundation patterns in two large savanna floodplains of South America: the Llanos de Moxos (Bolivia) and the Llanos del Orinoco (Venezuela and Colombia). - In: Hydrological Processes 18: 2103-2116. Hamilton, S.K. (2009): Flood plains. - In: LiKens, G.E. (ed.): Encyclopedia of inland waters. - Oxford: Elsevier: 378-386.

Hanagarth, W. \& J. Sarmiento (1990): Reporte preliminar sobre la geoecología de la sabana de Espíritu y sus alrededores (Llanos de Moxos, departamento del Beni, Bolivia). - In: Ecología en Bolivia 16: 47-75.

Hanagarth, W. (1993): Acerca de la geoecología de las sabanas del Beni en el noreste de Bolivia. - La Paz: Instituto de Ecología.

Holbrook, J. \& S.A. Schumm (1999): Geomorphic and sedimentary response of rivers to tectonic deformation: a brief review and critique of a tool for recognizing subtle epeirogenic deformation in modern and ancient settings. - In: Tectonophysics 305, 1-3: 287-306. Horton, B.K. \& P.G. DeCelles (1997): The modern foreland basin system adjacent to the Central Andes. In: Geology 25, 10: 895-898.

Horton, B.K. \& P.G. DeCelles (2001): Modern and ancient fluvial megafans in the foreland basin system of the central Andes, southern Bolivia: implications for drainage network evolution in fold-thrust belts. - In: Basin Research 13, 1: 43-63.

Ibañez, C. \& M. Pouilly (2004): Diversidad de hábitats acuáticos. - In: Pouilly, M., Beck, S.G., Moraes R., M. \& C. Ibañez (eds): Diversidad biológica en la 
Llanura de inundación del Río Mamoré. Importancia ecológica de la dinámica fluvial. - La Paz: Fundación Simón I. Patiño: 117-138.

Jones, L.S. \& S.A. Schumm (1999): Causes of avulsion: an overview. - In: SMITH, N.D. \& J. Rogers (eds): Fluvial Sedimentology IV. - Special publication of the International Association of Sedimentologists 28, Oxford: Wiley-Blackwell: 171-178.

LANgStroth, R. (1996): Forest islands in an Amazonian savanna of Northeastern Bolivia. - Unpublished Ph.D. dissertation, Madison: University of Wisconsin, Department of Geography.

LAtrubesse, E.M. (2003): The Late-Quaternary palaeohydrology of large South American fluvial systems. - In: Gregory, K.J. \& G. Benito (eds): Palaeohydrology: understanding global change. Chichester: John Wiley \& Sons Ltd: 193-212.

Lyon-Caen, H., Molnar, P. \& G. Suarez (1985): Gravity anomalies and flexure of the Brazilian Shield beneath the Bolivian Andes. - In: Earth and Planetary Science Letters 75, 1: 81-92.

MAKASKe, B. (2001): Anastomosing rivers: a review of their classification, origin and sedimentary products. In: Earth-Science Reviews 53, 3-4:149-196.

MaYLE, F.E. (2011): A review of Holocene rainforest ecotonal dynamics at opposite ends of the Amazon Bolivia versus Colombia. - In: Geographica Helvetica 66,3: 202-207.

Mayle, F.E., Burbridge, R. \& T.J. Killeen (2000): Millennial-scale dynamics of Southern Amazonian rain forests. - In: Science 290, 5500: 2291-2294.

Mayle, F.E., Langstroth, R.P., Fisher, R. \& P. Meir (2007): Long-term forest-savannah dynamics in the Bolivian Amazon: implications for conservation. - In: Philosophical Transactions of the Royal Society B 362, 1478: 291-307.

Mohrig, D., Heller, P.L., Paola, C. \& W.J. Lyons (2000): Interpreting avulsion process from ancient alluvial sequences: Guadalope-Matarranya system (northern Spain) and Wasatch Formation (western Colorado). - In: Geological Society of America Bulletin 112, 12: 1787-1803.

OuchI, S. (1985): Response of alluvial rivers to slow active tectonic movement. - In: Geological Society of America Bulletin 96, 4: 594-515.

PlafKer, G. (1964): Oriented lakes and lineaments of northeastern Bolivia. - In: Geological Society of America Bulletin 75, 6: 503-522.

Pouilly, M. \& S.G. BECK (2004): Geografía general. - In: Pouilly, M., Beck, S.G., Moraes R., M. \& C. IbaÑEz (eds): Diversidad biológica en la llanura de inundación del Río Mamoré. Importancia ecológica de la dinámica fluvial. - La Paz: Fundacíon Simón I. Patiño: 15-25.

Roche, M.-A. \& C.F. JAUREGUI (1988): Water resources, salinity and salt yields of the rivers of the Bolivian Amazon. - In: Journal of Hydrology 101, 1-4: 305-331.
Ronchail, J., Bourrel, L., Cochonneau, G., Vauchel, P., Phillips, L., Castro, A., Guyot, J.-L. \& E. De Oliveira (2005): Inundations in the Mamore basin (south-western Amazon - Bolivia) and sea-surface temperature in the Pacific and Atlantic Oceans. - In: Journal of Hydrology 302, 1-4: 223-238.

Schumm, S.A. (2005): River variability and complexity. - Cambridge: Cambridge University Press.

Servant, M., Fontes, J.-C., Rieu, M. \& J.-F. Saliège (1981): Phases climatiques arides holocènes dans le sud-ouest de l'Amazonie (Bolivie). - In: Comptes Rendus de l'Académie des Sciences, Paris, Série II 292: 1295-1297.

Sioli, H. (ed.) (1984): The Amazon. Limnology and landscape ecology of a mighty tropical river and its basin. - Monographiae Biologicae 56, Dordrecht, Boston, Lancaster: Dr. W. Junk Publishers.

SuÁrez-Soruco, R. (2000): Compendio de geología de Bolivia. - Revista Técnica de YPBF 18, La Paz.

TaYlor, Z.P., Horn, S.P., Mora, C.I., Orvis, K.H. \& L.W. Cooper (2010): A multi-proxy paleoecological record of late-Holocene forest expansion in lowland Bolivia. - In: Palaeogeography, Palaeoclimatology, Palaeoecology 293, 1-2: 98-107.

Vera, C., Higgins, W., Amador, J., Ambrizzi, T., Garreaud, R., Gochis, D., Gutzler, D., Lettenmaier, D., Marengo, J., Mechoso, C.R., Nogues-Paegle, J., Dias, P.L.S. \& C. Zhang (2006): Toward a unified view of the American monsoon systems. - In: Journal of Climate 19, 20: 4977-5000.

Zhou, J. \& K.-M. LAU (1998): Does a monsoon climate exist over South America? - In: Journal of Climate 11: 1020-1040.

\section{Abstract: Review of past and recent fluvial dynamics in the Beni lowlands, NE Bolivia}

The Beni lowlands in the southwestern Amazon Basin are characterized by a complex fluvial drainage pattern. Very little is known about the longer-term changes and the modern processes in this fluvial system. This paper reviews the existing literature concerned with past and recent fluvial processes in the Beni basin. It presents findings about potential controlling factors of longer-term fluvial variability in the Beni lowlands based on remote sensing research. It also describes the discovery of a previously unreported palaeocourse of the Río Mamoré. This river appears to have changed its course from NE to NNE due to probable discharge increase in the inbetween phase. Reasons for the increased discharge may be found in the transition to more humid conditions in the late Holocene with greater sediment supply in the rivers and thus greater chance of avulsions in the Beni basin.

Keywords: river avulsions, Amazon, Llanos de Moxos, Mamoré, Grande 


\section{Zusammenfassung: Ein Überblick zur heutigen und vorzeitlichen Dynamik im Beni-Tiefland, Nordost- Bolivien}

Das Beni-Tiefland im südwestlichen Amazonasbekken ist charakterisiert durch ein komplexes fluviales System, über dessen längerfristige Veränderungen und moderne Prozesse bisher wenig bekannt ist. In diesem Artikel wird die Literatur, die sich mit den vergangenen und rezenten fluvialen Prozessen im Beni-Becken befasst, zusammengefasst. Ein bisher nicht bekannter Paläoverlauf des Río Mamoré wurde anhand von Satellitenbildern untersucht. Der Río Mamoré verlagerte seinen Verlauf von NO nach NNO und erfuhr wahrscheinlich eine Abflusszunahme zwischen diesen beiden Phasen. Der Übergang zu feuchteren Bedingungen im späten Holozän könnte eine Abflusszunahme und/oder Zunahme der Sedimentfracht verursacht und so zu Flussverlagerungen im Beni-Becken geführt haben.

Schlüsselwörter: Flussverlagerungen, Amazonasgebiet, Llanos de Moxos, Mamoré, Grande

\section{Résumé: Dynamiques fluviales anciennes et récentes} dans les basses terres de Beni (nord-est de la Bolivie) Les basses terres du sud-ouest du bassin amazonien sont caractérisées par un système complexe de drainage fluvial, dont les changements à long terme et les processus contemporains sont encore mal connus. Cet article recense la littérature existante relative aux processus passés et actuels du bassin de Beni, utilise des données de télédétection afin de mettre en évidence certains des aspects de la variabilité fluviale à long terme des basses terres de Beni et discute les résultats de recherche à la lumière de certains facteurs de contrôle potentiels. L'article documente le tracé d'un ancien cours du Río Mamoré jusqu'ici inconnu. Le cours du Río Mamoré a été modifié du NE au NNE, ce qui a manifestement occasionné un accroissement de l'écoulement entre les deux phases. La transition vers des conditions plus humides à la fin de l'Holocène et/ ou un apport sédimentaire dans les rivières pourraient avoir causé cet accroissement, et par là, avoir conduit à des avulsions dans le bassin de Beni.

Mots-clés: avulsions fluviales, Amazonie, Llanos de Moxos, Mamoré, Grande

Anna Plotzki, Dipl. Umweltwissenschaftlerin, Institute of Geography, University of Bern, Hallerstrasse 12, CH-3012 Bern, Switzerland.

e-mail: plotzki@giub.unibe.ch

Dr. Jan-Hendrik May, School of Earth and Environmental Science, University of Wollongong, $2522 \mathrm{Wol}-$ longong NSW, Australia.

e-mail: hmay@uow.edu.au

Prof. Dr. Heinz Veit, Institute of Geography, University of Bern, Hallerstrasse 12, CH-3012 Bern, Switzerland.

e-mail: veit@giub.unibe.ch

Manuskripteingang/received/manuscrit reçu le 18.4.2011

Annahme zum Druck/accepted for publication/accepté pour publication: 24.10 .2011 